\title{
Effectiveness of E-Learning Technology on The Performance of the CSS NC II Trainees (Computer Systems Servicing) of Tesda Accredited Training Centers in TESDA-Kalinga
}

\author{
Ronald U. Wacas
}

\author{
Kalinga State University, Philippines
}

Received: 03 Oct 2020; Received in revised form: 20 Dec 2020; Accepted: 27 Dec 2020; Available online: 31 Dec 2020 (C)2020 The Author(s). Published by Infogain Publication. This is an open access article under the CC BY license (https://creativecommons.org/licenses/by/4.0/).

\begin{abstract}
E-learning is the term given to a method of schooling and learning environment in which students and teachers, or others interested in the exchanging of knowledge, do not interact physically but are separated by time, space, or both. The distance is bridged with the help of communication technology, including the Internet and emergent educational technologies. This study focused on the effectiveness of E-learning technologies on the performance of CSS (Computer Systems Servicing) Students of TESDA accredited training centers in Kalinga Province, Philippines. A quasi-experimental design or the pre-test-post-test equivalent groups design was used to determined E-learning technology's effectiveness in the teaching-learning process. The researcher used moodle platform in conducting online training. It was found out that e-learning is more effective in the learning process than the traditional method. This is supported by the experimental and control group's computed mean score, which is 31.38 and 22.67 respectively. This is similar to the findings of Novo-Corti, Varela-Candamio, and Ramil-Diaz (2013) that there is an increase in students' performance (grades and qualifications) when using the hybrid technology of e-learning.
\end{abstract}

Keywords-E-learning, CSS NC II Trainees, Accredited Training Centers, TESDA.

\section{INTRODUCTION}

With the rapid advancement of technology like the Internet, educational institutions are changing their teaching techniques to meet users' demands in providing an ideal learning environment. The use of e-learning approaches includes the opportunity to learn from the knowledge given remotely through mailing, accessing e-mails, online classes, online chat boards, video conferencing, CD Rom, etc. (Cappel 2004).

E-learning is the term given to a method of schooling and learning environment in which students and teachers, or others interested in the exchanging of knowledge, do not interact physically but are separated by time, space, or both. The distance is bridged with the help of communication technology, including the Internet and emergent educational technologies. E-learning may or may not be in real-time.

A more systematic concept of e-learning is 'the transmission by electronic means of a curriculum of learning, preparation, or education. E-learning requires the use of a computer or electronic device - in any way to offer training, education, or learning resources' (M. M. Maneschijn, 2005, p. 1).

According to Maltz et al. (2005), the term e-learning' is applied from various backgrounds, including distributed learning, online distance learning, and blended learning. Elearning, according to the OECD (2005), is characterized as the use of information and communication technologies in a variety of educational processes to promote and improve 
learning in higher education institutions and involves the use of information and communication technology as a supplement to conventional classrooms, online learning or a combination of both besides, according to Wentling et al. (2000), the word "e-learning" refers to the achievement and utilization of information that is primarily enabled and transmitted by electronic means. To them, e-learning depends on computers and networks. However, improvement is likely to be made in networks with diverse platforms, such as wireless and satellite, and mobile phones (Wentling et al., 2000). In their literature review on definitions for e-learning, Liu and Wang (2009) found that the features of the e-learning process are chiefly centered on the internet; global sharing and learning resources; information broadcasts and knowledge flow by way of network courses, and lastly, the flexibility of learning as the computer-generated environment for learning is created to overcome issues of distance and time (Liu and Wang, 2009). Gotschall (2000) argues that e-learning is proposed based on distance learning, thus transmitting lectures to distant locations through video presentations. However, Liu and Wang (2009) claim that the progression of communications technologies, particularly the internet, did transform distance learning into e-learning.

The development of multimedia and information technologies and the use of the internet as a new teaching tool has made radical changes in the traditional teaching process (Wang et al., 2007). According to Yang and Arjomand (1999), development in information technology has generated more choices for today's education. Agenda of schools and educational institutions have recognized e-Learning as having the prospect to transform people, knowledge, skills, and performance (Henry, 2001). According to Love and Fry (2006), colleges and other higher learning institutions are vying to advance online learning potential in a fast-growing cyber-education market. E-learning has been highly influential in higher education systems. The implementation and development of various e-learning technologies have contributed to several changes in higher education institutions, especially regarding their instructional delivery and support processes (Dublin, 2003). Just as there are different types of e-Learning, there are also different ways of employing the education technique. Algahtani (2011) established three distinct models for the use of e-learning in education, including the 'adjunct, integrated e-learning, and web, in its assessment of e-learning efficacy and experience in Saudi Arabia. The three ways of using e-Learning technologies, as discovered by Algahtani (2011), are described below. The "adjunct e-Learning is the situation in which e-Learning is employed as an assistant in the traditional classroom providing relative independence to the learners or students (Algahtani, 2011).

In the blended e-Learning, Algahtani (2011) and Zeitoun (2008) explained that, in using e-Learning, the delivery of course materials and explanations is shared between traditional learning method and e-learning method in the classroom setting. The third one, which is online, is devoid of traditional learning participation or classroom participation. In this form of usage, the e-Learning is total so that there is maximum independence of the learners or students (Algahtani,2011; Zeitoun, 2008). Zeitoun (2008) has explained that the online model is divided into individual and collaborative learning, where collaborative learning also consists of synchronous and asynchronous learning (Zeitoun, 2008).

In realization of the potentials of Technology in education, many countries in the developing world, including the least developed countries, are making significant investments in developing their ICT in education plans and bringing various ICT equipment and resources into schools. Even with too constrained financial resources, some educational institutions are purchasing or developing an Elearning system to provide a blended learning environment.ICT holds promise in providing not only anywhere and anytime access to knowledge but also equal opportunities for networking and communications that allow knowledge sharing, participation, and lifelong learning(ZHANG et al.2016)

Recognizing the challenge of the technological-age, most universities even have ICT classrooms (model classrooms). Some schools, especially in far-flung areas, are not E-learning technology due to the unavailability of electricity, unavailability of materials such as computers, teachers, limited knowledge of technology, and teachers' attitudes. Challenges on technology integration in teaching and learning various researchers have been trying to understand why teachers are less integrating e-learning technology in the teaching-learning process. In the Philippines, e-learning technologies are acquired through purchases using school funds or donations from government or private individuals. Tinio (2002), in his report, shows only half or less had been able to use the computers as an educational tool. Lack of facilities due to economic realities is one of the most significant challenges in the Philippine context. Secondly is the teacher's knowledge skill and attitude 
the use of technology for teaching requires the development of knowledge, skills, behaviors, and appropriate attitude (Kim and Baylor,2008). Lastly is the role of leadership. Most universities have partnered with IT Companies to create a virtual learning environment in which a wide range of levels and disciplines of academic degrees and certificate programs are managed through a consistent user interface standard throughout the institution.

This research study focused on the effectiveness of E-learning Technology on CSS trainees' performance to TESDA-Kalinga accredited training centers. It shall serve as baseline data to improve its currently deployed E-learning system to attain its vision-mission and objectives, mainly providing quality skills to its stakeholder.

\section{DESIGN AND METHODOLOGY}

This chapter presented the research method and procedure that will be used in the study. It contains a detailed description of the research process, including the data gathering procedure and the statistical tools for analyzing the data gathered in the study.

\section{Research Design}

The Quasi-experimental design or the pre-test - posttest equivalent groups design was utilized to determine Elearning Technology's effectiveness in the teaching-learning process. This design provided control of whom and when the measurement is applied. This is the pretest-Posttest equivalent groups' design was used in the classroom experiment when experimental and control groups were such naturally assembled groups as intact classes.

This is

$\begin{array}{lll}0_{1} & \mathrm{X} & 0_{2} \\ 0_{3} & \mathrm{C} & 0_{4}\end{array}$

Where:

$0_{1}$ and $0_{2}$ are pre-test observation results

$0_{3}$ and $0_{4}$ ate post-test observation results

The difference between the means of the $0_{1}$ and $0_{2}$ scores and the difference between the $0_{3}$ and $\mathrm{O}_{4}$ will be tested for statistical significance.

\section{Locale and Population of the Study}

The respondents were the 50 CSS trainees enrolled in their core competency subjects in TESDA accredited schools (Saint Tonis College, Bulanao, Tabuk City, Kalinga, and Saint Louis College of Bulanao) school year 2019-2020. The researcher used systematic sampling in the sub-grouping of the population wherein their names were arranged alphabetically, and all names fall under odd numbers for experimental. In contrast, all names under even numbers were utilized for controlled groups.

\section{Data Gathering Tool}

This study made use of two equivalent groups, one group for experimental and the other is controlled. The lecture was given to the first group using the E-learning system, which was treated as an experimental group, while the second group was lectured using the traditional method. Both groups were subjected to pre-test and post-test in the same subject matter they were taught.

Before implementing the two methods to both experimental and controlled groups, a 50 items multiplechoice test was given to the respondents to determine their performance level and then after which the same test was administered. The content of the 50 multiple-choice tests were all about computer troubleshooting.

\section{Validity and Reliability of the Instrument}

All learning materials that will be posted or delivered to the trainees through the e-learning portal will be subject to the LMS committee's approval. To test the questionnaire's reliability, the researcher printed 40 copies of questionnaires and gave them to 20 randomly selected respondents to answer. The questionnaires are numbered from 1-20. After the respondents answered the questionnaire, the researchers administered the other 20 same questionnaires to the same respondents. The gathered data were analyzed using Pearson-Product Moment Correlation to determine if the data are correlated.

\section{Data Gathering Procedure}

The researcher sought permission from the college president of the two training centers (Saint Louis College of Bulanao and Saint Tonis College) before the conduct of the research. It was followed by a pre-test administered among the CSS trainees (controlled and experimental group) of the two training centers. After the lessons were taught using the two different methods, a post-test was administered.

\section{Treatment of Data}

To determine the level of performance of the students, a standard evaluation scale was used: 
Performance Indicator of the Score Interval

$\begin{array}{ccc}\text { Scale } & \text { Score } & \text { Performance Level } \\ 5 & 41-50 & \text { Advance } \\ 4 & 31-40 & \text { Proficient } \\ 3 & 21-30 & \text { Approaching Proficient } \\ 2 & 11-20 & \text { Developing } \\ 1 & 0-10 & \text { Beginning }\end{array}$

Score interval 1-10 is interpreted as "Beginning," 1120 as "Developing;" 21-30 as "Approaching Proficiency;" 3140 as "Proficient;" and 41-50 as "Advanced." It will be used to describe the performance of the CSS trainees on their core competency subjects.

In deciding if the null hypothesis is accepted or rejected, the table below was used.

\begin{tabular}{|c|c|}
\hline Condition & Decission \\
\hline p.value $>0.05$ & Accept HO \\
\hline p.value $\leq 0.05$ & Reject HO \\
\hline
\end{tabular}

\section{Statistical Tools Used}

The following statistical tools were used to compute the gathered data:

Frequency Counts: This tool was used to determine the number of beginning, developing, approaching proficiency, proficiency, and advance.

Simple Mean. This tool was used to determine the average score of the respondents in their pre-test and post-test.

$$
\begin{gathered}
\mathrm{X}=\sum \mathrm{X} \\
\mathrm{N}
\end{gathered}
$$

Where: $\sum X=$ Total Score $\mathrm{N}=$ Number of respondents

Paired Sample T-test: This tool was used to determine if there is a significant difference in the pre-test and post-test scores of the experimental and control groups. The formula, according to Guerrero et al. (1992).

Independent T-Test: This tool was used to determine if there is a significant difference between the experimental and control groups on their pre-test or post-test scores.
The data were analyzed through the use of Statistical Packages for Social Sciences (SPSS).

\section{RESULTS AND DISCUSSION}

Table 1: Level of performance on the pre-test of the experimental group of CSS trainees of the TESDA accredited schools in their core competency subject

\begin{tabular}{|c|c|c|c|}
\hline Scale & Score & Frequency & Performance \\
\hline 1 & $0-10$ & 4 & Beginning \\
\hline 2 & $11-20$ & 9 & Developing \\
\hline 3 & $21-30$ & 0 & $\begin{array}{c}\text { Approaching } \\
\text { Proficiency }\end{array}$ \\
\hline 4 & $31-40$ & 0 & Proficient \\
\hline 5 & $41-50$ & 0 & Advance \\
\hline MEAN & \multicolumn{2}{|c|}{$\mathbf{1 2 . 9 2}$} & DEVELOPING \\
\hline
\end{tabular}

Table 1 shows the performance level on the pre-test of the experimental group of CSS trainees of the TESDA accredited schools in their core competency subject. As shown on the table, 4 respondents scored ranging from 0-10, which is leveled as beginning in performance, while 9 respondents scored ranging from 11-20, which is developing performance. It also shows that there is no student scored higher than 20.

Generally, the table shows that the mean score of the 13 respondents is 12.92 , which is developing performance.

Table 2. Level of performance on the post-test of the experimental group of CSS trainees of the TESDA accredited schools in their core competency subject

\begin{tabular}{|c|c|c|c|}
\hline Scale & Score & Frequency & Performance \\
\hline 1 & $0-10$ & 0 & Beginning \\
\hline 2 & $11-20$ & 1 & Developing \\
\hline 3 & $21-30$ & 5 & Approaching Proficiency \\
\hline 4 & $31-40$ & 5 & Proficient \\
\hline 5 & $41-50$ & 2 & Advance \\
\hline MEAN & \multicolumn{2}{|c|}{31.38} & PROFICIENT \\
\hline
\end{tabular}


Table 2 shows the performance level on the post-test of the experimental group of CSS trainees of the TESDA accredited schools in their core competency subject. As shown on the table, no respondent scored less than 11 or beginning in performance, 1 of the respondents scored ranging from 11-20, which is developing in performance, 5 respondents scored ranging from 21-30 which is approaching Table 3: T-test table on the significant difference in the performance level on the pre-test and post-test of the experimental group of CSS trainees of the TESDA accredited schools in their core competency subject.

\begin{tabular}{|c|c|c|c|c|c|c|c|c|c|}
\hline & \multicolumn{5}{|c|}{ Paired Differences } & \multirow[b]{3}{*}{$\mathrm{t}$} & \multirow[b]{3}{*}{$\mathrm{df}$} & \multirow[b]{3}{*}{ p.value } \\
\hline & & \multirow[b]{2}{*}{ Mean } & \multirow[b]{2}{*}{ Std. Deviation } & \multirow{2}{*}{$\begin{array}{l}\text { Std. Error } \\
\text { Mean }\end{array}$} & \multicolumn{2}{|c|}{$\begin{array}{l}95 \% \text { Confidence Interval } \\
\text { of the Difference }\end{array}$} & & & \\
\hline & & & & & Lower & Upper & & & \\
\hline $\begin{array}{c}\text { Pair } \\
1\end{array}$ & $\begin{array}{c}\text { PRE-TEST } \\
- \\
\text { POSTEST }\end{array}$ & -18.4615 & 8.17124 & 2.26630 & -23.3994 & -13.5237 & -8.146 & 12 & .000 \\
\hline
\end{tabular}

Table 3 shows the T-test table on the significant difference in the performance level on the pre-test and posttest of the experimental group of CSS trainees of the TESDA accredited schools in their core competency subject. As shown in the table, the computed t-value is -8.146 with a degree of freedom of 12 and a probability value of 0.000 . proficiency, 5 also scored ranging from $31-40$ which is proficient, and 2 of the respondents scored ranging from 41 50 which is advance.

Generally, the table shows that the mean score of the 13 respondents in their post-test is 31.38 , which is proficient in performance.

Table 4: Level of performance on the pre-test of the control group of CSS trainees of the TESDA accredited schools in their core competency subject.

\begin{tabular}{|c|c|c|c|}
\hline Scale & Score & Frequency & Performance \\
\hline 1 & $0-10$ & 2 & Beginning \\
\hline 2 & $11-20$ & 7 & Developing \\
\hline 3 & $21-30$ & 3 & Approaching Proficiency \\
\hline 4 & $31-40$ & 0 & Proficient \\
\hline 5 & $41-50$ & 0 & Advance \\
\hline MEAN & & $\mathbf{1 5 . 0 8}$ & DEVELOPING \\
\hline
\end{tabular}

Table 4 shows the performance level on the pre-test of the control group of CSS trainees of the TESDA accredited schools in their core competency subject.

As shown on the table, 2 respondents scored ranging from $0-10$, which is a beginning in performance, 7 respondents scored ranging from 11-20, which is developing, 3 respondents scored ranging from 21-30, which is
Since the p.value is less than the 0.05 margin of error, the null hypothesis is rejected. This means a significant difference in the performance level on the pre-test and posttest of the experimental group of CSS trainees of the TESDA accredited schools in their core competency subject.

approaching proficiency in performance. In contrast, no respondents scored higher than 30 .

Generally, the mean score of the 12 respondents is 15.08 , which is developing in performance. 
International Journal of English Literature and Social Sciences, 5(6)

Nov-Dec 2020 / Available online: https://ijels.com/

Table 5: Level of performance on the pre-test of the control group of the CSS trainees in TESDA accredited schools in their core competency subject

\begin{tabular}{|c|c|c|c|}
\hline Scale & Score & Frequency & Performance \\
\hline 1 & $0-10$ & 0 & Beginning \\
\hline 2 & $11-20$ & 5 & Developing \\
\hline 3 & $21-30$ & 5 & Approaching Proficiency \\
\hline 4 & $31-40$ & 1 & Proficient \\
\hline 5 & $41-50$ & 1 & Advance \\
\hline MEAN & \multicolumn{2}{|c|}{$\mathbf{2 2 . 6 7}$} & APPROACHING PROFICIENCY \\
\hline
\end{tabular}

Table 5 shows the performance level on the pre-test of the control group of the CSS trainees in TESDA accredited schools in their core competency subject.

. As shown on the table, no respondent scored ranging from $0-10$ or beginning performance, 5 respondents scored ranging from 11-20, which is developing in performance, 5 respondents scored ranging from 21-30 which is approaching proficiency, 1 respondent scored 31-40 which is proficient, and 1 respondent scored ranging from 41-50 which is advance in performance.

Generally, the table shows that the mean score of the 12 respondents is 22.67 , which is approaching proficiency.

Table 6: T-test table on the significant difference in the performance level on the pre-test and post-test of the control group of the CSS trainees in TESDA accredited schools on their core competency subject

\begin{tabular}{|c|c|c|c|c|c|c|c|c|c|}
\hline & \multicolumn{5}{|c|}{ Paired Differences } & \multirow[b]{3}{*}{$\mathrm{T}$} & \multirow[b]{3}{*}{ df } & \multirow{3}{*}{$\begin{array}{l}\text { Sig. (2- } \\
\text { tailed) }\end{array}$} \\
\hline & & \multirow[b]{2}{*}{ Mean } & \multirow[b]{2}{*}{ Std. Deviation } & \multirow{2}{*}{$\begin{array}{c}\text { Std. Error } \\
\text { Mean }\end{array}$} & \multicolumn{2}{|c|}{$\begin{array}{l}\text { 95\% Confidence } \\
\text { Interval of the } \\
\text { Difference }\end{array}$} & & & \\
\hline & & & & & Lower & Upper & & & \\
\hline Pair 1 & $\begin{array}{c}\text { PRE-TEST - } \\
\text { POSTC }\end{array}$ & -7.5833 & 8.58602 & 2.47857 & -13.0386 & -2.1280 & -3.060 & 11 & 0.011 \\
\hline
\end{tabular}

Table 6 shows the t-test table on the significant difference in the performance level on the pre-test and posttest of the control group of CSS trainees in TESDA accredited schools on their core competency subject.

As shown in the table, the computed t-value is 3.060 with a degree of freedom of 11 and a probability value of 0.011 .
Since the probability value is less than the 0.05 margin of error, the null hypothesis is rejected. There is a significant difference in the level of performance on the pretest and post-test of the control group of the CSS trainees in TESDA accredited schools on their core competency subject. 
Table 7: T-test table on the significant difference in the pre-test of the experimental and control groups of the CSS trainees in TESDA accredited schools on their core competency subject

\begin{tabular}{|c|c|c|c|c|c|c|c|c|}
\hline \multirow{3}{*}{\multicolumn{2}{|c|}{ PRETEST }} & \multicolumn{7}{|c|}{ t-test for Equality of Means } \\
\hline & & \multirow[t]{2}{*}{$\mathrm{t}$} & \multirow[t]{2}{*}{ df } & \multirow[t]{2}{*}{ p.value } & \multirow[t]{2}{*}{$\begin{array}{c}\text { Mean } \\
\text { Difference }\end{array}$} & \multirow[t]{2}{*}{$\begin{array}{l}\text { Std. Error } \\
\text { Difference }\end{array}$} & \multicolumn{2}{|c|}{$\begin{array}{l}\text { 95\% Confidence } \\
\text { Interval of the } \\
\text { Difference }\end{array}$} \\
\hline & & & & & & & Lower & Upper \\
\hline \multirow[t]{2}{*}{$\begin{array}{l}\text { Experimental- } \\
\text { Control }\end{array}$} & $\begin{array}{c}\text { Equal } \\
\text { variances } \\
\text { assumed }\end{array}$ & -1.275 & 23 & .215 & -2.1603 & 1.69398 & -5.66452 & 1.34401 \\
\hline & $\begin{array}{c}\text { Equal } \\
\text { variances } \\
\text { not assumed }\end{array}$ & -1.251 & 17.918 & .227 & -2.1603 & 1.72667 & -5.78905 & 1.46854 \\
\hline
\end{tabular}

Table 7 shows the t-test table on the significant difference on the pre-test of the experimental and control group of CSS trainees of the TESDA accredited schools in their core competency subject.

As shown in the table, the computed t-value on equal variance assumed is -1.275 with a degree of freedom of 23 and a probability value of 0.215 .
Since the p.value is more significant than the 0.05 margin of error, the null hypothesis is accepted. It means that there is no significant difference on the pre-test of the experimental and control group of CSS trainees of the TESDA accredited schools on their core competency subject.

Table 8: T-test table on the significant difference in the post-test of the experimental and control group of CSS trainees of the TESDA accredited schools on their core competency subjects.

\begin{tabular}{|c|c|c|c|c|c|c|c|c|}
\hline \multirow{3}{*}{ POSTTEST } & & \multicolumn{7}{|c|}{ t-test for Equality of Means } \\
\hline & & \multirow[t]{2}{*}{$\mathrm{T}$} & \multirow[t]{2}{*}{ Df } & \multirow[t]{2}{*}{$\begin{array}{l}\text { Sig. } \\
\text { tailed) }\end{array}$} & \multirow[t]{2}{*}{$\begin{array}{l}\text { Mean } \\
\text { Difference }\end{array}$} & \multirow[t]{2}{*}{$\begin{array}{l}\text { Std. Error } \\
\text { Difference }\end{array}$} & \multicolumn{2}{|c|}{\begin{tabular}{ll}
$55 \%$ & \multicolumn{2}{l}{ Confidence } \\
Interval of the \\
Difference
\end{tabular}} \\
\hline & & & & & & & Lower & Upper \\
\hline \multirow{2}{*}{$\begin{array}{l}\text { Experimental- } \\
\text { Control }\end{array}$} & $\begin{array}{l}\text { Equal } \\
\text { variances } \\
\text { assume }\end{array}$ & 2.735 & 23 & .012 & 8.7179 & 3.18702 & 2.12510 & 15.31080 \\
\hline & $\begin{array}{l}\text { Equal } \\
\text { variances } \\
\text { not assume }\end{array}$ & 2.705 & 20.505 & .013 & 8.7179 & 3.22292 & 2.00564 & 15.43025 \\
\hline
\end{tabular}

Table 8 shows the T-test table on the significant difference on the post-test of the experimental and control group of CSS trainees of the TESDA accredited schools in their core competency subject.
As shown in the table, the computed t-value on equal variance assumed is 2.735 with a degree of freedom of 23 and a probability value of 0.012 .

Since the p.value is less than the 0.05 margin of error; hence, the null hypothesis is rejected. There is a 
significant difference in the post-test of the experimental and control group of CSS trainees of the TESDA accredited schools on their core competency subject.

\section{CONCLUSION}

Based on the computed results of the gathered data, it was found out that there is a significant difference in the post-test of the experimental and control group of CSS trainees of the TESDA accredited schools in their core competency subject. It shows that the e-learning system differs on the result of post-test compared to the traditional method. It is concluded that the e-learning system is more effective in the learning process than the traditional method. This is supported by the computed mean score of the experimental and control group. The experimental group has a mean score of 31.38 , which is proficient in performance, while the control group has only a 22.67 mean score, which is approaching proficiency. This is similar to the findings of Novo-Corti, Varela-Candamio, and Ramil-Diaz (2013) that there is an increase in students' performance (grades and qualifications) when using the mixed technology of elearning.

\section{RECOMMENDATION}

Based on the conclusions, the following recommendations were formulated.

1. The e-learning system should be implemented both in the private and public training institution.

2. Learners should be exposed to the e-learning system.

3. Administrators should provide training to the teachers about the e-learning system.

4. Trainers should utilize the e-learning system positively and facilitate the implementation.

5. Future researchers should continue investigating the impact of e-learning systems.

\section{REFERENCES}

[1] Angelo, T. A. (1998). Principles to teach by. Accounting Education News, 4(5), 11-14 Borg, W.R., Gall, J. P., \& Gall, M. D. (1993). Applying educational research: A practical guide (3rd ed.). New York: Longman.

[2] Catalano. J. A. (1999). Using multidimensional scaling and cluster analysis for understanding information processing and schizophrenia. Genetic, Social, and General psychology. Monograph.125 (3, serial no.313)
[3] Bayraktar, S. (2002). A meta-analysis of the effectiveness of computer assisted instruction in science education. Journal of Research on Technology in Education, 34, 173-191.

[4] Bailey, H. J. \& Milheim, W. D. (1991, February). A comprehensive model for designing interactive video based materials. Proceedings of the Ninth Conference on Interactive Instruction Delivery, 1991. Society for Applied Learning Technology Conference, Orlando, FL.

[5] Alshehri, A. (2005). Assessing faculty attitudes toward the significant factors for facilitating the implementation of online courses at the Institute of Public Administration in Saudi Arabia. Mississippi State University.

[6] Dalziel, J. (2003). Implementing learning design: The learning activity management system (LAMS). Proceedings of the ASCILITE 2003 conference, Adelaide.

[7] El Mansour, B., \& Mupinga, D. (2007). Students'positive and negative experiences in hybrid and online classes. College Student Journal, 41(1), 242.

[8] Gable, G., Sedera, D., \& Chan, T. (2008). Re-conceptualizing information system success : the IS-Impact Measurement Model. Journal of the Association for Information Systems, 9(7), 377-408.

[9] Myers, B., Kappelman, L., \& Victor, R. (1997). Prybutok, A comprehensive model for assessing the quality and productivity of the information systems function: toward a theory for information systems assessment. Information Resources Management Journal, 10(1), 6-25. Myers, M. D. (1997). Qualitative Research in Information Systems. [Article]. MIS quarterly, 21(2), 241-242.

[10] Rabaa'i, Ahmad A. \& Gable, Guy G. (2009) Extending the ISImpact Model into the higher education sector. In ICICS2009 : 7th International Conference on Information and Communications Systems, 7-10 Dec., 2009, Macau.Reuben, B. (1988). Communication and human behaviour: USA:Macmillan Publishing Company.

[11] Trespalacios, J. \& Rand, J. (2015). Using asynchronous activities to promote sense of community and learning in an online course. International Journal of Online Pedagogy and Course Design, 5(4), 1- 13. doi:10.4018/IJOPCD.2015100101

[12] Tsai, C. W. (2015). Applying web-based co-regulated learning to develop students' learning and involvement in a blended computing course. Interactive Learning Environments, 23(3), 344-355.

[13]Honey, P. and A. Mumford, 1992. The manual of learning styles. Maidenhead: Peter Honey Publications. Khribi, M.K., M. Jemni and O. Nasraoui, 2007. Toward a hybrid recommender system for e- learning personalization based on web usage mining techniques and information retrieval. Proceedings of World Conference on E-Learning in Corporate, Government, Healthcare, and Higher Education (E-learn 2007), 7(1): 6136-6145. 